\title{
Precision thinning of 'Royal Gala' apple trees using the fruit growth model
}

\author{
A.D. Rufato ${ }^{1}$, T.L. Robinson ${ }^{2}$ and L. Rufato ${ }^{3}$ \\ ${ }^{1}$ Embrapa Grape and Wine, Vacaria, Brazil; ${ }^{2}$ Dept. of Horticulture, NYSAES, Cornell University, Geneva, USA; \\ ${ }^{3}$ Santa Catarina State University, Agroveterinary Science Center, Lages, Brazil.
}

\begin{abstract}
In 2013 we thinned mature 'Royal Gala' apple trees on M.9 rootstock using the precision thinning protocol developed by Robinson. To assess the initial flower bud load we counted the number of flower buds on 5 trees per treatment at the pink bud stage. We then thinned the trees with one of 2 thinning protocols using sequential chemical thinning sprays: 1) Promalin (benzyl adenine $+\mathrm{GA}_{4+7}$ ) at full bloom (FB) followed by three successive sprays of benzyl adenine (BA)+carbaryl at petal fall, 12 $\mathrm{mm}$ fruit size and $18 \mathrm{~mm}$ fruit size; 2) BA at FB then three sprays of BA + carbaryl at petal fall, 12 and $18 \mathrm{~mm}$; and 3) untreated control. After each spray we used the fruit growth rate model developed by Greene to predict cumulative thinning efficacy to that point. We implemented this model by tagging 15 representative spurs tree-1 on the 5 test trees of each treatment at full bloom. At petal fall each fruit within each tagged cluster was marked with a dot to identify its position in the cluster. On the third day after each thinner spray and the seventh day after each spray we measured the diameter of each fruit in the 15 clusters on each of the 5 trees. These data were analyzed with the fruit growth rate model to determine the number of fruits still growing on the tree after each spray. The model indicated that BA sprayed at FB reduced the fruit number tree-1 $32 \%$ compared to the untreated control. Promalin at FB did not reduce fruit number tree ${ }^{-1}$. When the successive thinning treatments were completed and fruits were $25 \mathrm{~mm}$ diameter we again measured fruit diameters of the tagged spurs and calculated the number of fruits persisting on each tree. Treatment 2 had the lowest fruit number tree ${ }^{-1}(44 \%$ of the untreated control) while Treatment 1 had slightly greater fruit number tree-1 than treatment $1(52 \%$ of the untreated control). At harvest the final number of fruits per trees was significantly less than we estimated by using the model when fruits were $22 \mathrm{~mm}$. This overestimation of final fruit set by the fruit growth rate model could be due to later climatic conditions, which induced a "June drop".
\end{abstract}

Keywords: Malus $\times$ domestica, predict thinning, crop load, bloom thinning, post bloom thinning

\section{INTRODUCTION}

Fruit or flower thinning is commercially practiced in order to maximize crop value by optimizing marketable fruit size and yield, as well as to improve fruit color, shape quality and return bloom (Byers, 2003). Chemical thinning is the primary method of apple thinning in the world. It is estimated that over $90 \%$ of the commercial apple growers in the world use some form of chemical flower and fruit thinning (Childers et al., 1995), nevertheless apple growers have observed problems of variability and unpredictability in chemical thinning (Robinson and Lakso, 2011).

Several chemical thinners have been used for apple trees such benzyl adenine (BA), naphthalene acetic acid (NAA), gibberellins, Promalin and other chemicals mainly at postbloom applications. BA is an efficient thinner, which also increases fruit size by stimulating cell number in the fruit cortex (Byers, 2003). Elfving and Cline (1993) reported Promalin was not as effective as BA for thinning mature 'Empire' apples trees.

Mathematical models have been developed to increase the predictability of chemical 
thinning. They include the carbohydrate model (Robinson and Lakso, 2011), the pollen tube growth model (Yoder et al., 2013) and the fruit growth rate model (Greene, 2008; Greene et al., 2013). The fruit growth model is based on the assumption that if fruit growth rate of a particular fruit over a certain period is less than $50 \%$ of the growth rate of the fastest growing fruit on the tree during the same growth period, it will abscise; whereas if fruits growing in excess of $50 \%$ of the growth rate on the fastest growing fruit, will persist (Greene et al., 2013). McArtney and Obermiller (2010) observed that the efficacy of different postbloom chemical thinners was successfully predicted using a model based on fruit growth rates.

Both the carbohydrate and the fruit growth rate models can be used together; the first one to predict thinning response before a chemical thinning spray and the second model to asses the results of a thinning spray and to determine if another chemical thinning spray is needed (Robinson et al., 2014).

The objective of the current study was to evaluate the performance of the fruit growth rate model when used with a sequential chemical thinning spray program on mature 'Royal Gala' apple trees.

\section{MATERIALS AND METHODS}

In 2013, at the New York State Agricultural Experiment Station in Geneva, we thinned mature 'Royal Gala' apples trees on M.9 rootstock trained to a vertical axis system using the precision thinning protocol developed by Robinson et al. (2013). To assess the initial flower bud load we counted the number of flowers buds on 5 trees per treatment at pink bud stage. The initial number of flowers (fruitlets) per tree was calculated by multiplying the number of flower cluster by 5 .

We thinned the trees beginning at full bloom with one of 2 thinning protocols:

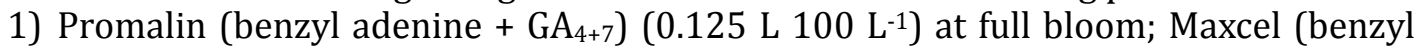
adenine) (0.5 L $\left.100 \mathrm{~L}^{-1}\right)+$ carbaryl $\left(0.125 \mathrm{~L}_{\left.100 \mathrm{~L}^{-1}\right)}\right.$ at petal fall $(5 \mathrm{~mm}$ of fruit

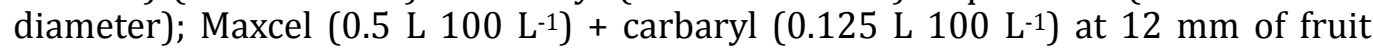
diameter; and Maxcel (0.5 L $\left.100 \mathrm{~L}^{-1}\right)+$ carbaryl $\left(0.125{\left.\mathrm{~L} 100 \mathrm{~L}^{-1}\right)}^{-1}\right.$ mineral oil $\left(0.125 \mathrm{~L}^{\left.100 \mathrm{~L}^{-1}\right)}\right.$ at $18 \mathrm{~mm}$ of fruit diameter;

2) Maxcel (0.5 L $\left.100 \mathrm{~L}^{-1}\right)$ at full bloom; Maxcel (0.5 L $\left.100 \mathrm{~L}^{-1}\right)+$ carbaryl $(0.125 \mathrm{~L} 100$

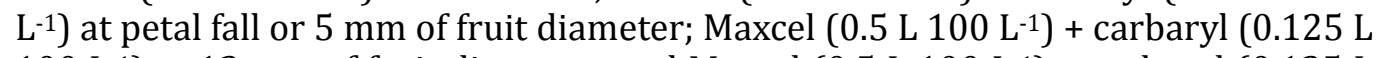

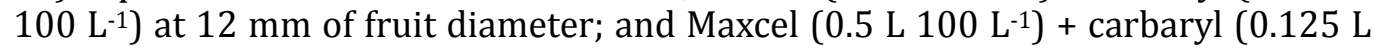
$\left.100 \mathrm{~L}^{-1}\right)+$ mineral oil $\left(0.125{\left.\mathrm{~L} 100 \mathrm{~L}^{-1}\right)}^{2}\right.$ at $18 \mathrm{~mm}$ of fruit diameter.

Both protocols were compared with an untreated control. Treatments were applied with an airblast $3.5 \mathrm{~m}$ tall and $4 \mathrm{~m}$-wide tunnel sprayer (Lipco), which limited drift to adjacent rows. The trees had a dilute tree row volume of $2000 \mathrm{~L}^{2}$ water ha-1. Sprays were applied with $840 \mathrm{~L}$ water ha-1 and chemicals were concentrated by a factor of 2.38 to provide the proper amount of chemical per ha as if a full dilute spray had been used.

After each spray was applied, the fruit growth rate model developed by Greene et al. (2013) was used to predict thinning efficacy. The model was implemented by tagging 15 representative spurs per tree on 5 test trees of each treatment at full bloom. At petal fall, each fruit within each tagged cluster was marked with dot (1-5 dots) to identify its position in the cluster. On the third day after each chemical thinning spray we measured the fruit diameter of each fruit in the 15 clusters on each of the 5 test trees. These data were analyzed with fruit growth rate model. The model estimated the number of persisting fruits on the tree after each thinning sprays.

At bloom, we also tagged three representative branches per tree (lower canopy, midcanopy and upper canopy) and counted the number of flower clusters on each branch. At harvest we counted the number of fruit on each tagged branch to calculate fruit set, which was calculated as the ratio of fruits harvested/flower clusters on each of the three branches. At harvest the final fruit number and yield tree ${ }^{-1}$ were recorded.

The experiment was organized as a randomized complete block design with 5 replications. Blocking was done by location in the field. Each replicate consisted of 3 trees with the center tree used for data and others serving only as guard trees. Data were analyzed 
by ANOVA using SAS general linear models. Mean separation was done by least significant difference $(\mathrm{P}=0.05)$.

\section{RESULTS AND DISCUSSION}

In the 2013 season, the initial load of flower buds was high, with an average of 886 flower cluster tree ${ }^{-1}$ which when multiplied by 5 resulted in an initial fruit load of 4,430 fruitlets tree ${ }^{-1}$ in the prebloom time. We calculated a final target fruit number after thinning needed to achieve a high yield (70 $\mathrm{t} \mathrm{ha}^{-1}$ ) of large sized fruit (100 count) of only 335 fruits tree $^{-1}$. The ratio between initial flowers cluster numbers and final target fruit number was 2.6, indicating that flower bud load was above the optimum and could have been reduced by more aggressive pruning before chemical thinning like recommended by Robinson et al. (2014).

Both chemical thinning treatments reduced fruit set, number of fruits and fruit yield when compared to the untreated control, but there was no significant difference between the thinning treatments (Table 1). The thinning treatments reduced the number of fruits tree $^{-1}$ by $44 \%$ when Promalin was applied and by $50 \%$ when Maxcel was applied at bloom. Chemical thinning had a positive effect on fruit weight of 'Gala' whether applying Promalin ${ }^{\circledR}$ or Maxcel ${ }^{\circledR}$ as the bloom treatment.

Table 1. Effect of Promalin, Maxcel + Sevin on final crop load, yield efficiency, number of fruits, yield, fruit size and fruit set of 'Gala'/M.9 apple trees.

\begin{tabular}{|c|c|c|c|c|c|c|}
\hline Thinning treatment & $\begin{array}{c}\text { Crop load } \\
\text { (no } \mathrm{cm}^{-2} \\
\text { TCA) }\end{array}$ & $\begin{array}{c}\text { Yield eff. } \\
\text { (kg cm-2 } \\
\text { TCA) }\end{array}$ & $\begin{array}{c}\text { Fruit } \\
\text { no tree-1 }\end{array}$ & $\begin{array}{l}\text { Yield tree-1 } \\
(\mathrm{kg})\end{array}$ & $\begin{array}{l}\text { Fruit size } \\
\text { (g) }\end{array}$ & $\begin{array}{l}\text { Fruit set } \\
\text { (fruits } \\
\text { cluster }{ }^{-1} \text { ) }\end{array}$ \\
\hline $\begin{array}{l}\text { 1. Promalin at full bloom; } \\
\text { Maxcel + carbaryl } \\
\text { at petal fall ( } 5 \mathrm{~mm} \text { of fruit diameter); } \\
\text { Maxcel + carbaryl at } 12 \mathrm{~mm} \\
\text { fruit diameter; and Maxcel + } \\
\text { carbaryl + mineral oil } \\
\text { at } 18 \mathrm{~mm} \text { fruit diameter }\end{array}$ & 7.7 & 1.35 & 343 & 60.0 & 176 & 0.42 \\
\hline $\begin{array}{l}\text { 2. Maxcel at FB; Maxcel at } 5 \mathrm{~mm} \text {; } \\
\text { Maxcel + carbaryl at } 12 \mathrm{~mm} \text {; } \\
\text { Maxcel + carbaryl + oil at } 18 \mathrm{~mm}\end{array}$ & 7.6 & 1.23 & 312 & 50.6 & 164 & 0.35 \\
\hline 3. Untreated control & & 2.01 & 618 & 86.2 & 142 & 0.76 \\
\hline LSD P $\leq 0.05$ & 3.7 & 0.39 & 149 & 15.2 & 34 & 0.35 \\
\hline Significance & *** & $* \star *$ & $* * *$ & $* * *$ & $* *$ & ${ }^{* *}$ \\
\hline
\end{tabular}

We used the fruit growth rate model to estimate the number of persisting fruit after each spray and to analyze the impact of each spray in the respective thinning protocols. The fruit growth rate model showed that Maxcel was more efficient than Promalin to reducing fruit number when sprayed at bloom, whereas Promalin gave no thinning at bloom and was not significantly different than the untreated control (Table 2). The model indicated that Maxcel sprayed at FB reduced fruit number tree-1 $31 \%$ compared to the untreated control. The advantage of Maxcel over Promalin treatment observed after the full bloom spray disappeared as the thinning season progressed with the subsequent sprays, but both treatments always had less fruit than the untreated control. If hypothetically, the farmer chooses only to do blossom thinning, Maxcel would be a better choice than Promalin.

When the thinning treatments were completed and fruits were $22 \mathrm{~mm}$ diameter, Treatment 2 had the lowest fruit number tree-1 $(44 \%$ of the untreated control) while Treatment 1 had slightly greater fruit number tree-1 $(52 \%$ of the untreated control). However, both treatments has substantially greater fruit number than the target fruit number. At harvest the final number of fruits per trees was significantly less than we estimated when fruit were $22 \mathrm{~mm}$. The final fruit number was close to the target fruit number. The cause for this significant fruit drop is not known but it was also evident in the untreated control. It is likely that climatic conditions in June, possibly a carbohydrate deficit, 
stimulated a "June drop" in 2013. The overestimation of final fruit set by the fruit growth rate model could be a problem if growers achieve the target fruit number during the thinning window and then subsequently additional fruits drop during June drop the final fruit number could be below the target fruit number. However, this is not likely since when lower fruit numbers are achieved with thinning sprays it is less likely that a carbohydrate deficit will reduce fruit growth rate enough to cause fruit drop in June (Lakso et al., 2007; Lakso and Robinson, 2014).

Table 2. Initial, final and target number of fruit tree ${ }^{-1}$ and number of fruit tree ${ }^{-1}$ predicted with the fruit growth rate model after each chemical thinning spray.

\begin{tabular}{|c|c|c|c|c|c|c|c|c|}
\hline \multirow[b]{3}{*}{ Thinning treatment } & \multicolumn{8}{|c|}{ Fruit number tree ${ }^{-1}$} \\
\hline & \multirow[b]{2}{*}{$\begin{array}{l}\text { Initial } \\
\text { pre- } \\
\text { bloom }\end{array}$} & \multicolumn{5}{|c|}{ Predicted from fruit growth rate model } & \multirow[b]{2}{*}{$\begin{array}{l}\text { Final at } \\
\text { harvest }\end{array}$} & \multirow[b]{2}{*}{ Target } \\
\hline & & $\begin{array}{l}\text { After } \\
\text { bloom } \\
\text { spray }\end{array}$ & $\begin{array}{c}\text { After } \\
\text { petal fall } \\
\text { spray }\end{array}$ & $\begin{array}{l}\text { After } 12 \\
\text { mm } \\
\text { spray }\end{array}$ & $\begin{array}{l}\text { After } 18 \\
\text { mm } \\
\text { Spray }\end{array}$ & $\begin{array}{c}\text { At } 22 \\
\mathrm{~mm}\end{array}$ & & \\
\hline $\begin{array}{l}\text { 1. Promalin at FB then } 3 \\
\text { Maxcel }+ \text { Sevin sprays at } \\
\text { petal fall, } 12 \text { and } 18 \mathrm{~mm} \\
\text { fruit size }\end{array}$ & 4430 & 1524 & 992 & 933 & 756 & 673 & 343 & 335 \\
\hline $\begin{array}{l}\text { 2. Maxcel at FB then } 3 \text { Maxcel } \\
+ \text { Sevin sprays at petal fall, } \\
12 \text { and } 18 \mathrm{~mm} \text { fruit size }\end{array}$ & 4430 & 1051 & 992 & 981 & 579 & 567 & 312 & 335 \\
\hline 3. Untreated control & 4430 & 1536 & 1217 & 1299 & 980 & 1288 & 618 & 335 \\
\hline
\end{tabular}

\section{CONCLUSION}

The fruit growth rate model was useful to predict fruit number per tree and allowed an assessment of the efficacy of each spray and a tracking of the progress of reducing fruit number tree-1 toward the target fruit number. The model overestimated final fruit set in our study. Both bloom and postbloom thinning protocols were efficient on reducing fruit load of 'Gala' trees. Even though Maxcel was more efficient than Promalin as a bloom treatment this difference disappeared after subsequent Maxcel + carbaryl sprays.

\section{Literature cited}

Byers, R.E. (2003). Flower and fruit thinning and vegetative: fruiting balance. In Apples: Botany, Production, and Uses, D.C. Ferree, and I.J. Warrington, eds. (Wallingford, Oxon: CAB International), p.409-436.

Childers, N.F., Morris, J.R., and Sibbett, G.S. (1995). Modern Fruit Science (Auburndale, Florida: AgScience), p.106120.

Elfving, D.C., and Cline, R.A. (1993). Cytokinin and ethephon affects crop load, shoot growth, and nutrient concentration of 'Empire' apple trees. HortScience 28, 1011-1014.

Greene, D.W. (2008). A growers guide to predicting the response to a chemical thinner application. www.umass.edu/fruitadvisor/2008/predictfruitset2008.

Greene, D.W., Lakso, A.N., Robinson, T.L., and Schwallier, P. (2013). Development of a fruitlet growth model to predict thinner response on apples. HortScience 48, 584-587.

Lakso, A.N., and Robinson, T.L. (2014). Integrating physiological models in applied fruit crop research. Acta Hortic. 1058, 285-290 https://doi.org/10.17660/ActaHortic.2014.1058.33.

Lakso, A.N., Robinson, T.L., and Greene, D.W. (2007). Using an apple tree carbohydrate model to understand thinning responses to weather and chemical thinners. NY Fruit Quarterly 15 (3), 17-20.

McArtney, S.J., and Obermiller, J.D. (2010). Evaluation of a model to predict the response of 'Gala' apples to chemical thinners. Acta Hortic. 884, 581-586 https://doi.org/10.17660/ActaHortic.2010.884.75.

Robinson, T.L., and Lakso, A.N. (2011). Predicting chemical thinner response with a carbohydrate model. Acta Hortic. 903, 743-750 https://doi.org/10.17660/ActaHortic.2011.903.103.

Robinson, T., Lakso, A., Greene, D., and Hoying, S. (2013). Precision crop load management. NY Fruit Quarterly 21 (2), 3-9. 
Robinson, T.L., Hoying, S., Miranda Sazo, M., and Rufato, A.R. (2014). Precision crop load management: Part 2. New York Fruit Quarterly 22 (1), 9-13.

Yoder, K.S., Peck, G.M., Combs, L.D., and Byers, R.E. (2013). Using a pollen tube growth model to improve apple bloom thinning for organic production. Acta Hortic. 1001, 207-214 https://doi.org/10.17660/ActaHortic. 2013.1001.23. 
